\title{
FILSAFAT ETIKA IBN MISKAWAIH
}

\author{
Abdul Hakim \\ Jurusan Akidah Filsafat Fakultas Ushuluddin dan Humaniora \\ IAIN Antasari Banjarmasin
}

\begin{abstract}
Ibn Miskawayh is one of the Islamic philosophers who focused on the study of ethics. In his "Tahdheeb al-Akblaq" he reflects on the concept of ethics systematically using Greek philosophy and combine it with the Qur'an and hadith. Although compared to the concept of ethics of Immanuel Kant's deontology, ethics Ibn Miskawayh not apply well to the rule of law. However, the severity of the effort is a big contribution on the development of ethical discourse that connects "rational ethics" and "ethical revelation".
\end{abstract}

Kata kunci: etika Islam, etika keutamaan, etika kebajikan

\section{Pendahuluan}

Etika pada umumnya diidentikkan dengan moral (atau moralitas). Namun, meskipun sama terkait dengan dengan baik-buruk tindakan manusia, etika dan moral memiliki perbedaan pengertian. Moral lebih diarahkan pada pengertian "nilai baik dan buruk dari setiap perbuatan manusia", sedangkan etika lebih ditekankan pada pengertian "ilmu yang mempelajari tentang baik dan buruk". Dengan demikian dapat dikatakan bahwa etika merupakan bagian teori tentang baik dan buruk, adapun moral adalah bagian praktiknya.

Dalam tradisi Barat, pada umumnya, pandangan-pandangan menganai etika dapat dikelompokkan menjadi 3 (tiga), yaitu: etika hedonistik, utilitarian, dan deontologis. ${ }^{2}$ Hedonisme mengarahkan etika kepada keperluan untuk menghasilkan sebanyak-banyaknya kesenangan bagi manusia.Etika utilitarian mengoreksinya dengan menambahkan bahwa kesenangan atau kebahagiaan yang dihasilkan oleh suatu etika yang baik adalah kebahagiaan bagi sebanyak mungkin orang, dan bukan kesenangan atau kebahagiaan individual.Adapun etika deontologis memandang bahwa sumber bagi perbuatan etis adalah rasa kewajiban yang diperoleh dari "nalar praktis" dan bukan dari "nalar teoritis".Secara umum, pada kenyataannya hasil pemikiran para filsuf Barat merupakan bagian dari ketiga aliran besar tersebut atau bahkan mengambil prinsip-prinsip dasar etika dari aliran yang ada dan kemudian mereka rumuskan dalam sebuah sistem etika.

Kalau dihubungkan dengan etika Islam, jelaslah bahwa etika Barat punya berbagai kesamaan dan perbedaan antara keduanya.Etika Islam juga berpihak pada teori etika yang bersifat fitri.Di sinilah letak bertemunya etika Islam dengan etika Yunani seperti Socrates dan Plato, juga dengan etika Barat Modern, Immanuel Kant. Di sisi lain etika Islam, meskipun juga menekankan rasionalitas, akan tetapi etikanya juga berdasarkan wahyu sebagai sumber tindakan etis. Demikian juga yang dilakukan oleh Ibnu Miskawaih bahwa dalam mengemukakan argumen-argumen dalam sistem etikanya tanpa menomorsatukan wahyu untuk memecahkan berbagai kesulitan teoritis. Oliver Leaman ${ }^{3}$ menegaskan

\footnotetext{
${ }^{1}$ Haidar Bagir, Etika "Barat", Etika Islam, pengantar dalam Antara Al-Ghazali dan Kant: Filsafat Etika Islam, (Bandung: Mizan, 2002), h. 15.

${ }^{2}$ Haidar Bagir, Etika "Barat”, Etike Islam, h. 15-16.
} 
bahwa hal ini merupakan kombinasi keanggunan gaya, relevansi praktis, dan ketegaran filosofis dalam diri Ibnu Miskawaih yang melanggengkan pengaruhnya di dunia Islam.

Ibn Miskawaih menulis sejumlah topik yang luas, seperti dilakukan oleh banyak orang sezamannya.Meskipun karya-karyanya mungkin tidak begitu terkenal dibandingkan dengan karya filsuf Islam semisal Ibn Sina.Dari sejumlah karya-karyanya menegaskan bahwa dia telah menyumbangkan pemikirannya terhadap perkembangan pemikiran filsafat.Dalam filsafat, klaim utama Ibn Miskawaih yang perlu diperhatikan terletak pada sistem etikanya yang tersusun dengan baik.

\section{Biografi Ibnu Miskawaih}

Nama lengkapnya Ibn Miskawaih (w. 421 H/1030 M) adalah Abu Ali Ahmad bin Muhammad bin Ya'qub Miskawaih al-Khazin ar-Razi al Isfahani. Ia berasal dari kota Ray, Iran, dan karena ia dikenal dengan ar-Razi ${ }^{4}$ atau dipanggil juga dengan Abu Khazin. ${ }^{5}$ Disebutkan bahwa ayahnya kemungkinan beragama Majusi yang kemudian memeluk Islam. ${ }^{6}$

Ia berguru pada sejumlah ulama, antara lain: Abu Bakr Ahmad ibn Kamil al-Qadhi (w.350 H/ 960 M) mengenai Tarikh al-Thabari; Ibn al-Khammar, penafsir kenamaan karya-karya Aristoteles, adalah gurunya dalam bidang ilmu filsafat; Abu Thayyib al-Razi, seorang ahli kimia. Dari beberapa pandangan tokoh pemikir Islam ada yang menyebutkan bahwa ia tidak mampu berfilsafat. Sedangkan Iqbal menyebut dia sebagai salah seorang pemikir teistis, moralis dan sejarawan Parsi paling terkenal. ${ }^{7}$

Sebagian besar hidupnya digunakan untuk mengabdikan diri kepada pemerintahan Dinasti Bani Buwaihi, dalam sejarahnya Bani Buwaihi merupakan dinasti yang beraliran Syi'ah.Salah seorang kalangan Dinasti Bani Buwaihi yang paling berpengaruh terhadap perjalanan hidupnya adalah Abu Fadhl ibn al-'Amid (w.360 H/970 M). Ibn Miskawaih mengabdikan dirinya selama tujuh tahun sebagai pustakawan dan penjaga perpustakaan besar milik Ibn al-'Amid. Di sini ia dapat menuntut ilmu dan banyak memperoleh banyak hal positif selama bergaul dengan pangeran ini, dan mendapat kedudukan yang berpengaruh di ibukota pemerintahan Bani Buwaihi saat itu. ${ }^{8}$

Di akhir masa hidupnya, Ibn Miskawaih banyak menyibukkan dirinya untuk belajar dan menulis.M. M. Syarif menyebutkan ada 18 buah karya yang ditulis oleh Ibn Miskawaih. Di antara karyanya tersebut hanya 7 buah yang masih bisa kita temukan adalah: (1) Al Fauz al Asghar (kalam dan studi agama-agama); (2)Tajarib al Umam (sejarah tentang banjir besar yang ditulis pada tahun 369 H/979 M); (3) Tahdzib al Akhlaq (mengenai akhlak); (4) Risalah fi al Ladzdzat wal Alam fi Jauhar al Nafs; (5) Ajwibah wa As'ilah fi al-Nafs wal Aql; (6) Al Jawab fi al Masa'il al Tsalats; dan (7) Thaharat al-Nafs. ${ }^{?}$

Dalam konteks etika, dia berbicara banyak dalam karyanya Tahdzib al-Akhlaq. Dalam kitabnya ini dia merumuskan konsep untuk membangun sebuah etika yang bisa mendatangkan kebahagian bagi indivdu dan masyarakat, dimana masyarakat yang dihadapinya saat itu akhlaknya sangat rusak.

318.

${ }^{3}$ Seyyed Hossein Nasr dan Oliver Leaman, Ensiklopedi Tematis Filsafat Islam (Buku Pertama), (Bandung: Mizan, 2003), h.

${ }^{4}$ Muhsin Lalib, Para Filosof Sebelum dan Sesudah Mulla Shadra, (Jakarta: Al-Huda, 2005), h. 109.

${ }^{5}$ M. M. Syarif (ed), Para Filosof Muslim, (Bandung: Mizan, 1996), h. 83

${ }^{6}$ M. M. Syarif (ed), Para Filosof Muslim, h. 83.

${ }^{7}$ M. M. Syarif (ed), Para Filosof Muslim, h. 83-84.

${ }^{8}$ Hadariansyah AB, Pengantar Filsafat Islam: Mengenal Filosof-filosof Muslimdan Filsafat Mereka, (Banjarmasin: Kafusari Press, 2012), h. 74-75.

${ }^{9}$ M. M. Syarif (ed), Para Filosof Muslim, h. 84-85. 
Karyanya ini juga menegaskan bahwa di samping dia telah menulis pemikiran tentang etika, dia juga seorang yang juga telah melaksanakan dengan baik apa yang ditulisnya tersebut. ${ }^{10}$

\section{Etika Ibnu Miskawaih}

\section{Kebaikan dan Keburukan}

Manusia merupakan makhluk yang memiliki perilaku khas, dan makhluk selainnya tidak ada yang memilikinya. Perilaku tersebut muncul dari kemampuan berpikirnya. Karenanya, setiap orang yang pemikirannya lebih tepat dan benar, serta pilihannya lebih baik, berarti kesempurnaan kemanusiaannya lebih besar. Manusia paling baik adalah manusia yang paling mampu melakukan tindakan yang tepat buatnya, yang paling memperhatikan syarat-syarat substansinya, yang membedakan dirinya dari seluruh benda alam yang ada.

Menurut Ibnu Miskawaih kebaikan merupakan hal yang dapat dicapai oleh manusia dengan berupaya dan dengan hal yang berkaitan dengan tujuan diciptakannya manusia; sedangkan keburukan merupakan hal yang menjadi penghambat manusia mencapai kebaikan, baik itu berupa kemauan dan upayanya, ataupun berupa kemalasan dan keengganannya mencari kebaikan.

Para filsuf terdahulu membagi kebaikan dalam beberapa kategori, yaitu: karena sebagian kenaikan itu mulia, sebagian terpuji, sebagian bermanfaat, dan sebagian lagi kebaikan yang masih berbentuk potensi. $^{11}$

Menurut Ibn Miskawaih, kebaikan adalah suatu keadaan di mana kita sampai kepada batas akhir dan kesempurnaan wujud. Kebaikan adakalanya umum, dan adakalanya khusus.Di atas semua kebaikan itu terdapat kebaikan mutlak yang identik dengan wujud tertinggi.Semua bentuk kebaikan secara bersama-sama berusaha mencapai kebaikan mutlak tersebut.Kebaikan Umum tadi adalah kebaikan bagi seluruh manusia dalam kedudukannya sebagai manusia.Sedangkan kebaikan khusus adalah kebaikan bagi seseorang secara pribadi.Kebaikan dalam bentuk terakhir inilah yang dinamakan kebahagiaan.Dengan demikian antara kebaikan dan kebahagiaan dapat dibedakan.Kebaikan mempunyai identitas tertentu yang berlaku umum bagi manusia, sedangkan kebahagiaan berbedabeda tergantung pada orang-orang yang berusaha memperolehnya.Pengertian kebahagiaan telah banyak dibicarakan oleh pemikir-pemikir Yunani yang pokoknya terdapat dua versi, yaitu pandangan pertama yang diwakili oleh Plato, mengatakan bahwa hanya jiwalah yang dapat mengalami kebahagiaan. Karena itu selama manusia masih hidup atau selama jiwa masih terkait dengan badan, maka selama itu pula tidak akan diperoleh kebahagiaan itu. ${ }^{12}$

\section{Kebajikan adalah Titik Tengah}

Ibn Miskawaih menyatakan bahwa kebajikan merupakan titik tengah antara dua ujung, sedangkan keburukan berada di ujung-ujung titik tengah tersebut.Kebajikan berada di titik tengah dapat dipahami dari letaknya yang berada di antara dua kehinaan dan posisi yang paling jauh dari dua kehinaan itu. Karenanya, jika kebajikan itu bergeser sedikit saja dari posisinya ke posisi yang lebih rendah, maka kebajikan itu mendekati salah satu kehinaan, dan akan berkurang nilainya menurut dekatnya dengan kehinaan yang dicenderunginya. Mencapai titik tengah tersebut memang sulit sekali, apalagi untuk

\footnotetext{
${ }^{10}$ M. M. Syarif (ed), Para Filosof Muslim, h. 85

${ }^{11}$ Ibn Miskawaih, Menuju Kesempurnaan Akblak: Buku Daras Pertama tentang Filsafat Etika, diterjemahkan oleh Helmi Hidayat dari Tahdzib al-Akblak, (Bandung: Mizan, 1999), h. 40-41.

${ }^{12}$ http://teosufi.webs.com/apps/blog/show/6939648-hakikat-manusia-menurut-ibnu-miskawaih (diakses 18-01-2012)
} 
mempertahankannya bila telah tercapai.

Ibn Miskawaih mendasarkan teori keutamaan moralnya pada posisi al wasath (pertengahan). ${ }^{13}$ Doktrin jalan ini sebenarnya sudah dikenalkan oleh filosuf sebelumnya, seperti Mencius, Palto, Aristoteles dan filsuf Muslim Al Kindi. Ibn Miskawaih secara umum memberikan pengertian "pertengahan" (jalan tengah) tersebut antara lain dengan berkesinambungan, moderat, harmoni, utama, mulia, atau posisi ektrim kelebihan dan ekstrim kekurangan masing-masing jiwa manusia.

Menurutnya, setiap sifat keutamaan memiliki dua ekstrim kekurangan, yang tengah adalah terpuji dan yang ekstrim adalah tercela. Posisi tengah yang dimaksudkana adalah suatu standar atau perinsip umum yang berlaku bagi manusia. Posisi tengah yang sebenarnya adalah satu, yakni keutamaan yang disebut garis lurus. Pokok sifat keutamaan itu terbagi menjadi empat, yaitu bikmah (kebijaksanaan), 'iffah (kesucian), syaja'ah (keberanian), 'adalab (keadilan), sedangkan yang jelek ada delapan. Rinciannya adalah nekad, pengecut, rakus, dingin hati, kelancaran, kedunguan, aniaya, dan teraniaya.

Penjelasan lebih mendetail dapat diperhatiakan tabel sebagai berikut:

\begin{tabular}{|c|l|c|}
\hline $\begin{array}{c}\text { Ekstrim Kekurangan } \\
(\text { Al Tafrith })\end{array}$ & $\begin{array}{l}\text { Posisi Tengah } \\
(\text { Al Was } \text { th })\end{array}$ & $\begin{array}{c}\text { Ekstrim Kelebihan } \\
(\text { Al } \text { Ifrat })\end{array}$ \\
\hline Kedunguan & Kebijaksanaan & Kelancangan \\
\hline Pengecut & Keheranian & Nekad \\
\hline Dingin hati & Menahan diri & Rakus \\
\hline Teraniaya & Keadilan & Aniaya \\
\hline
\end{tabular}

Ibn Miskawaih mengakui bahwa posisi tengah sifatnya relatif. Maka alat yang menjadi ukuran untuk memperolah sikap tengah ini adalah akal dan ajaran agama. Doktirn jalan tengah ini dapat dipahami sebagai doktrin yang mengandung arti dinamis dan fleksibel. Jadi dengan doktrin jalan tengah manusia tidak akan kehilangan arah dalam kondisi apapun.

Setiap keutamaan tersebut memiliki cabangnya masing-masing. Hikmah atau kebijaksanaan memiliki tujuh cabang, yaitu ketajaman intelegensi, kuat ingatan, rasionalitas, tangkas, jernih ingatan, jernih pikiran, dan mudah dalam belajar. 'Iffah atau menjaga diri memiliki dua belas cabang, yaitu malu, ketenangan, sabar, dermawan, kemerdekaan, bersahaja, kecenderungan kepada kebaikan, keteraturan, menghias diri dengan kebaikan, meninggalkan yang tidak baik, ketenangan, dan kehatihatian.

Adapun syaja'ah atau keberanian berkembang menjadi sembilan cabang, yaitu berjiwa besar, pantang takut, ketenangan, keuletan, kesabaran, murah hati, menahan diri, keperkasaan, dan memiliki daya tahan yang kuat atau senang bekerja berat.

Sementara keadilan (al 'adalab) oleh Ibn Miskawaih dibagi ke dalam tiga macam, yaitu keadilan alam, keadilan adat istiadat, dan keadilan Tuhan. Selanjutnya Ibn Miskawaih berpendapat bahwa posisi jalan tengah tersebut bisa diraih dengan memadukan fungsi syariat dan filsafat. Syariat berfungsi efektif bagi terciptanya posisi tengah dalam jiwa bernafsu dan jiwa berani. Sedangkan filsafat berfungsi efektif bagi terciptanya posisi tengah jiwa berfikir.

Dengan demikian, perinsip keadilan menjadi renungan dan juga harus dilaksanakan dalam kehidupan yang sekecil-kecilnya, karena hal ini akan menambah kua;itas hidup seseorang menjadi manusia yang mampu menggunakan akal cerdas, yang selanjutnya akan selalu mendapat ridha Allah swt.

${ }^{13}$ Ibn Miskawaih, Menuju Kesempurnaan Akblak, h. 51-53. 
Menurut Miskawaih asas semua keutamaan (al fadhilab) adalah cinta kepada semua manusia. Manusia tidak akan mencapai kepada tingkat kesempurnaan kecuali dengan memelihara jenisnya dan menunjukkan pengertian terhadap sesama jenisnya. Selanjutnya Miskawaih menjelaskan bahwa cinta tersebut tidak akan tampak bekasnya kecuali jika manusia berada di tengah-tengah masyarakat dan saling berinteraksi satu sama lain di dalamnya. Ibn Miskawaih tidak sependapat dengan mereka yang mencari keutaman/kebajikan melalui hidup asketik, mengasingkan diri dari pergaulan masyarakat. Karena orang yang demikian tidak akan bisa mencapai keutamaan-keutamaan insani. ${ }^{14}$ Tegasnya jalan untuk mencapai keutamaan di sini adalah dengan mengembangkan segala aspek psikologis dan bakatnya melalui hidup bermasyarakat, bergaul dengan manusia lainnya, sehingga memperoleh jenis kebahagiaan lain yang belum ditemukan saat sekarang.

\section{Kebahagiaan}

Menurut Ibn Miskawaih kebahagiaan merupakan puncak dan kesempurnaan dari kebaikan. Dalam konteks ini, maka kebahagiaan yang benar-benar sempurna hanyalah dinikmati orang-orang yang khusus dan sempurna pula. Kebahagian tersebut menurut Oliver Leaman ${ }^{15}$ adalah kebahagian yang terwujud dari hubungan mistik antara jiwa yang bebas dan realitas Ilahi. Tingkatan ini jelaslah merupakan tingkat kebagaian yang lebih tinggi daripada yang diperoleh melalui kesempurnaan intelektual. Dalam batas ini tampaknya Ibn Miskawaih juga dipengaruhi oleh Aristoteles, dimana Aristoteles menegaskan bahwa sesuatu yang paling membahagiakan manusia adalah filsafat atau perenungan hal-hal yang abadi dan Ilahi. ${ }^{16}$

Kebahagiaan dalam konsepsi Ibn Miskawaih digambarkan sebagai sesuatu yang paling nikmat, paling utama, paling baik, dan paling sejati.Kenikmatan yang terkandung dalam kebahagian terbagi kepada 2 (dua) bagian, yakni kenikmatan pasif dan kenikmatan aktif.

Kenikmatan pasif dimiliki oleh manusia dan binatang tak berakal yang bentuknya disertai hawa nafsu dan emosi balas dendam. Kenikmatan seperti ini hanyalah kenikmatan aksidental yang biasanya cepat hilang dan musnah, bahkan dapat berubah menjadi penderitaan atau sesuatu yang menjijikkan. Sedangkan kenikmatan aktif adalah kenikmatan yang lahir dari kekuatan intelektual dan di bawah naungan cahaya Ilahi, sehinggga kenikmatan dalam bentuk ini tidak akan berubah dan selalu tetap selamanya. ${ }^{17}$ Kebahagiaan tertinggi tersebut terwujud dengan berusaha melepaskan tuntutan-tuntutan dunia ini dan kemudian menerima emanasi-emanasi yang melimpah dari atas yang akan menyempurnakan intelek dan memungkinkan untuk disinari oleh cahaya Ilahi. ${ }^{18}$

Mulyadhi Kartanegara ${ }^{19}$ dalam bukunya Menembus Batas Waktu: Panorama Filsafat Islam, berdasarkan analisisnya, mencoba mengkategorikan kebahagiaan dalam pemikiran Ibn Miskawaih ke dalam 5 (lima) macam atau jenjang kebahagiaan yang dapat diperoleh dan dirasakan manusia.

Jenjang pertama, yaitu kebahagian fisik atau sensual, yang biasa juga dikenal dengan kesenangan (pleasure). Kebahagiaan jenis ini sering dipandang banyak orang sebagai satu-satunya kebahagiaan. Misalnya ada orang yang beranggapan kalau kaya pasti dia akan bahagia. Di sini bukan berarti kebahagian seperti ini menjadi tidak penting. Kebahagiaan model ini juga perlu untuk menopang

\footnotetext{
${ }^{14}$ Ibn Miskawaih, Menuju Kesempurnaan Akblak, h. 54-55.

${ }^{15}$ Seyyed Hossein Nasr dan Oliver Leaman, Ensiklopedi Tematis Filsafat Islam, h. 114-115.

${ }^{16}$ Franz Magnis-Suseno, 13 Tokoh Etika: Sejak Zaman Yunani Sampai Abad ke-19, (Yogyakarta: Kanisius, 2003), h. 33.

${ }^{17}$ Ibn Miskawaih, Menuju Kesempurnaan Akblak, h.107-108.

${ }^{18}$ Seyyed Hossein Nasr dan Oliver Leaman, Ensiklopedi Tematis Filsafat Islam, h. 314

${ }^{19}$ Mulyadhi Kartanegara, Menembus Batas Waktu: Panorama Filsafat Islam, (Bandung: Mizan, 2005), h. 70-75.
} 
jenjang-jenjang kebahagiaan lainnya.

Dalam menyikapi kebahagian fisik tersebut, filsuf merumuskan cara hidup filosofis yang sangat menekankan kesederhanaan. Disebutkan bahwa al-Farabi hidup sangat sederhana dan bahkan bersahaja, baik dalam soal makanan maupun pakaian, dalam kehidupannya di Istana Saif al-Daulah, di Aleppo, Suriah. Dia tidak mau dipusingkan oleh hal-hal keduniaan, dan sebagian besar hidupnya dihabiskan untuk menulis dan mengajar. Sangat pantaslah kalau dia diberi gelar guru kedua (al-mu'allim al-tsani) setelah Aristoteles. Hal ini juga tampaknya sejalan dengan kehidupan Ibn Miskawaih yang diwarnai kehidupan Istana dan politik di Dinasti Buwaih, di mana sebagian hidupnya digunakan untuk studi dan menulis, di samping juga dia pernah terlibat dalam dunia politik. Ibn Miskawaih juga lekat dengan gelar guru ketiga (al-mu'allim al-tsalits.

Jenjang kedua adalah kebahagiaan mental, kebahagian yang mungkin masih berkaitan dengan indra lahir, tetapi utamanya dengan indra batin. Kebahagian jenis ini bentuknya lebih abstrak daripada kebahagian fisik semata. Kesenangan mental yang sesungguhnya bisa ditemukan dalam kebaghagiaan imajiner, yaitu kebahagiaan pada tingkat imajinasi, oleh filsuf Muslim dipandang sebagai salah satu indra batin.

Imajinasi yang dilakukan oleh pelukis untuk menghasilkan suatu karya seni, menimbulkan kebahagiaan tersendiri, terutama bagi dirinya dan pencinta seni. Bahkan dalam menghasilkan karyanya itu sering lupa makan dan minum. Ini menunjukkan bahwa kebahagiaan mental tidak kalah nikmatnya, bahkan bisa mengalahkan kebahagiaan atau kesenangan fisik.

Jenjang ketiga adalah kebahagiaan intelektual, yakni kebahagiaan yang diperoleh manusia dari ilmu pengetahuan. Al-Qur'an mempertanyakan "Apakah sama orang yang berilmu dengan yang tidak berilmu?" Jawabnya tentu tidak. Perbedaannya adalah seperti orang yang melek dan orang buta. Orang yang berilmu ibarat orang yang melek, dengan ilmunya ia bisa keluar dari hutan belantara,kesesatan, menuju jalan yang terang dan kembali dengan aman sampai ke tepat tinggalnya.

Kebahagian intelektual tentunya lebih langgeng, bila dibandingkan dengan kebahagiaan fisik, seperti makan, karena makan bisa ada kenyangnya, sedangkan ilmu pengetahuan tidak akan ada kenyangnya. Oleh karena itu,selama kita memiliki ilmu, selama itu juga kita akan merasakan kebahagiaan. Bahkan uniknya lagi kebahagiaan intelektual terkadang bisa mengalahkan kebahagiaan fisik, berupa makanan, minuman, atau hubungan seksual.

Jenjang keempat adalah kebahagian moral. Salah satu bentuk kebahagiaan moral dalam konteks ilmu adalah rasa bahagia yang dicapai ketika telah mampu menerapkan ilmu (teoritis) ke dalam kehidupan sehari-hari. Al-Qur'an sendiri menurut persepsi Muhammad Iqbal sangat menekankan tindakan daripada ide. Dari aspek moral, orang baik adalah ia yang telah memiliki perilaku baik, dan bukan hanya mengetahui bahwa perilaku yang terpuji itu baik. Kebahagiaan dan ketenangan akan dirasakan oleh orang yang mengetahui jalan hidup yang baik sekaligus menjalani hidup yang baik.

Jenjang kelima adalah kebahagiaan spiritual. Bagi Ibn Miskawaih kebahagian moral memang tingkatan kebahagiaan yang tinggi, akan tetapi masih ada kebahagian tertinggi, yakni kebahagiaan spiritual. Hubungan secara vertikal melalui ibadah merupakan salah satu sarana untuk mencapai kebahagiaan spiritual. Tujuan ibadah shalat, misalnya, adalah membentuk moral yang baik dan mencegah perbuatan keji maupun mungkar. Akan tetapi, apabila seseorang sudah memiliki moral yang baik tidaklah dia harus berhenti atau tidak lagi melaksanakan shalat. Di sini dapat dipahami bahwa kebahagian moral saja tidak dapat membawa kepada kebahagian tertinggi, berupa kebahagian spiritual. 


\section{Analisis: Etika Keutamaan vs Etika Kewajiban}

Ajaran etika yang diformulasikan oleh Ibn Miskawaih dalam karya magnum opus-nya Tahdzib al-Akblaq secara garis besar memang memuat etika keutamaan, yakni lebih memfokuskan pada aspek being manusia (what kind of person I be?) saya harus menjadi orang yang bagaimana? Etika keutamaan memang tidak begitu menyoroti perbuatan satu demi satu, apakah sesuai atau tidak dengan norma moral, tetapi lebih memfokuskan pada manusia itu sendiri. Tujuan dari etika semacam ini adalah untuk mengarahkan menjadi orang yang memiliki etika yang baik. Menurut Zainul Kamal, etika Ibn Miskawaih yang dijabarkannya dalam Tahdzib al Akblaq merupakan perpaduan pemikiran filosofis dengan menggunakan firman al-Qur'an dan hadis Nabi Muhammad saw., dengan gaya pemikirannya yang sistematis, ia bermaksud menanamkan dalam diri kita kualitas-kualitas moral dalam tindakantindakan utama secara spontan. ${ }^{20}$ (Pengantar, Ibn Miskawaih: 14/ lihat: M. Alfan: 208).

Etika keutamaan sejauh ini memang sangat penting dalam tradisi kajian etika dan merupakan teori etika yang tertua. Etika ini sudah diajarkan oleh Socrates, Plato dan Aristoteles dalam ranah filsafat Yunani dan dikembangkan lebih berabad abad lamanya. Ibn Miskawaih merupakan tokoh yang menempati posisi sentral dalam tradisi etika filosofis Muslim. (Pengantar, Ibn Miskawaih: 22) Menurut penelaahan Ibn al-Khatib pemikiran Ibn Miskawaih juga mempengaruhi Imam al-Ghazali dalam karyanya Ibya 'Ulum al-Din. ${ }^{21}$

Dalam perkembangan sekarang etika keutamaan memang terkadang tidak terlalu mendapat perhatian lagi, hal ini sejalan dengan perkembangan teori etika, terutama sejak kemunculan teori etika yang dikembangkan oleh Immanuel Kant (1724-1804). Etika dalam pemikiran Kant lebih memberi tekanan pada kewajiban, sehingga rumusan etikanya lebih dikenal dengan "etika kewajiban".Etikanya ini bermuara pada suatu kehendak yang ingin melakukan kebaikan atau yang disebut dengan kehendak baik. Sejauh seseorang berkehendak baik, ia baik, tanpa pembatasan. Kehendak baik itu selalu baik dan dalam kebaikannya tidak tergantung pada sesuatu di luarnya. Menurut Kant, manusia bukan merupakan makhluk roh murni, tetapi ia juga makhluk alami, yang sangat besar kemungkinannya terpengaruh dengan hawa nafsu, emosi, kecenderungan dan dorongan batin, kebutuhan fisik dan psikis. Karenanya manusia juga bisa melakukan tindakan kejahatan.Moralitas bagi Kant adalah upaya manusia untuk melakukan kewajibannya sesuai dengan hati nuraninya untuk melakukan kebaikan yang dihadapkan dengan berbagai tarikan dan dorongan yang bersifat indrawi dan alami. ${ }^{22}$ Dalam praktiknya etika kewajiban lebih didasarkan pada pertimbangan-pertimbangan rasional dan obyektif serta yakin bahwa tindakan yang dikerjakan merupakan sebuah kebaikan.

Dalam realitas kehidupan, kita tidak lepas dari 2 (dua) teori etika tersebut. Di satu sisi manusia berkeinginan untuk mewujudkan dirinya menjadi manusia yang bermoral, memiliki sifat keutamaan (akhlak yang mulia) dan mencapai kebahagiaan. Di sisi lain manusia juga dihadapkan pada berbagai pilihan (imperatif kategoris) yang harus dilakukan dalam menyikapi kehidupan ini. Etika kewajiban mengarahkan manusia pada apa yang harus dilakukan? (what should I do?). Etika kewajiban kalau dihubungkan dengan hukum atau norma akan lebih aplikatif. Pemenuhan kewajiban kita untuk mematuhi hukum akan lebih terkendali dengan etika kewajiban, karena kewajiban kita untuk mematuhi dan menjunjung tinggi semua hukum yang telah ditetapkan. Memenuhi kewajiban bukanlah suatu yang mudah, seperti contoh: menurut aturan yang berlaku bahwa masyarakat tidak boleh buang

\footnotetext{
${ }^{20}$ Zainul Kamal, Kata Pengantar, Menuju Kesempurnaan Akblak: Buku Daras Pertama tentang Filsafat Etika, h. 14

${ }^{21}$ Ibnu al-Khatib, Kata Pengantar, Menuju Kesempurnaan Akblak: Buku Daras Pertama tentang Filsafat Etika, h. 26.

${ }^{22}$ Franz Magnis-Suseno, 13 Tokoh Etika, h. 143-144.
} 
sampah sembarangan, faktanya sering kita menyaksikan pengendara mobil ataupun motor yang membuang sampah sembarangan di jalan raya.

Dalam hal penegakan hukum, menurut penulis etika kewajiban lebih mengarahkan seseorang untuk mematuhi hukum yang berlaku, sehingga pemahaman terhadap etika kewajiban sangat penting dalam mengarahkan manusia agar bertindak baik dan moralis.Kant menegaskan bahwa paham moral yang dimiliki manusia adalah bersifat apriori dan berdasarkan akal praktis, yakni pengertian mengenai baik dan buruk yang mendahului segala pengalaman. ${ }^{23}$

Akan tetapi hal ini bukanlah untuk menafikan pentingnya juga etika keutamaan. K. Bertens ${ }^{24}$ menegaskan bahwa ada beberapa argumen yang memperlihatkan pentingnya etika keutamaan: (1) Dalam kehidupan sehari-hari kelakukan moral kita lebih baik dituntun oleh keutamaan. (2) Membatasi diri agar berlaku sesuai dengan norma atau moral belum cukup untuk dapat disebut seorang yang baik dalam arti sepenuhnya, karena dalam hidup juga diperlukan sifat keutamaan yang terkadang lebih mementingkan aspek kemanusiaan. (3) Etika keutamaan saja adalah buta, jika tidak dipimpin oleh norma atau prinsip. Dengan begitu antara etika kewajiban dan etika keutamaan saling berhubungan dan saling membutuhkan.Moralitas selalu berkaitan dengan prinsip serta aturan dan sekaligus juga dengan kualitas manusia itu sendiri, dengan sifat-sifat wataknya.

Konsep etika keutamaan Ibn Miskawaih yang sangat filosofis juga sekaligus memuat muatan religius, memakai analisa Amin Abdullah ${ }^{25}$ ketika melihat perbandingan antara etika al-Ghazali dan Kant, sangatlah tepat sebagai sebuah paradigma dalam mengembangkan wacana etika. Etika yang hanya dilandaskan kepada wahyu belumlah merupakan konsep yang memadai. Hal ini bukan berarti norma-norma wahyu itu yang tidak memadai, melainkan konsepsi itu sendiri yang tidak memadai. Meskipun boleh jadi tepat secara emosional dan psikologis, ia tidaklah memadai tidak secara intelektual. Sebaliknya, etika yang hanya berlandaskan "rasio" saja, tampaknya merupakan penyederhanaan yang berlebihan. Hanya kerjasama antara "etika wahyu" dan "etika rasional" yang akan menyelamatkan manusia dari keadaan terperangkap dalam keterpecahan kepribadian (split personality).

\section{Penutup}

Pemikiran etika (al-falsafah al-akblaq) Ibn Miskawaih yang terefleksi dalam kitabnyaTabdzib alAkhlaq merupakan suatu pemikiran yang sistematis, yang memaparkan bagaimana menanamkan kualitas-kualitas moral dalam diri seseorang dan melaksanakannya dalam tindakan sehari-hari secara spontan. Dalam tulisan ini, penulis lebih fokus kepada model pemikiran etika Ibn Miskawaih dan poin-poin yang mendasar dalam studi etika, seperti: kebaikan, keburukan, sifat keutamaan, kebahagiaan dan cara mewujudkannya.

Ibn Miskawaih dalam pemikiran etikanya mencoba memadukan antara pemikiran filsuf Yunani dengan ajaran Islam, sehingga menghasilkan sebuah konsep etika yang sangat religius sekaligus rasional. Model etika yang dikembangkan oleh Ibn Miskawaih model etika eudemonisme yang dikembangkan oleh Aristoteles, yakni suatu konsep etika yang menitikberatkan pada usaha mewujudkan kebahagiaan. Etika Ibn Miskawaih juga memfokuskan pada penanaman sifat-sifat keutamaan, seperti keberanian, kesucian, keadilan, dan kebijaksanaan. Meskipun model etika seperti ini masih memiliki kekurangan, karena masih perlunya didukung oleh norma atau prinsip yang harus dipatuhi untuk mengatur

\footnotetext{
${ }^{23}$ http:/ /grelovejogja.wordpress.com/2009/04/20/etika-kewajiban-immanuel -kant/

${ }^{24}$ K. Bertens, Etika, (Jakarta: Gramedia, 2002), h. 213-216.

${ }^{25}$ Amin Abdullah, Antara Al-Ghazali dan Kant: Filsafat Etika Islam, h. 218-220.
} 
ketertiban dan keteraturan hidup manusia, akan tetapi juga merupakan suatu model yang bisa dikembangkan oleh filsuf atau intelektual etika, yakni konsep etika yang religius dan rasional.

\section{DAFTAR PUSTAKA}

Bertens, K., (2002). Etika, Jakarta: Gramedia.

Hadariansyah AB, (2012). Pengantar Filsafat Islam: Mengenal Filosof-filosof Muslimdan Filsafat Mereka, Banjarmasin: Kafusari Press.

http://grelovejogja.wordpress.com/2009/04/20/etika-kewajiban-immanuel -kant/diakses 20-012012.

http://teosufi.webs.com/apps/blog/show/6939648-hakikat-manusia-menurut-ibnu-miskawaih, diakses 18-01-2012.

Ibn Miskawaih, (1999). Menuju Kesempurnaan Akblak: Buku Daras Pertama tentang Filsafat Etika, diterjemahkan oleh Helmi Hidayat dari Tahdzib al-Akhlak, Bandung: Mizan.

Kartanegara, Mulyadhi, (2005). Menembus Batas Waktu: Panorama Filsafat Islam, Bandung: Mizan.

Lalib, Muhsin, (2005). Para Filosof Sebelum dan Sesudab Mulla Shadra, Jakarta: Al-Huda, 2005.

Nasr, Seyyed Hossein dan Oliver Leaman, (2003). Ensiklopedi Tematis Filsafat Islam (Buku Pertama), Bandung: Mizan.

Suseno, Franz Magnis, (2003). 13 Tokoh Etika: Sejak Zaman Yunani Sampai Abad ke-19, Yogyakarta: Kanisius.

Syarif, M. M. (ed), (1996). Para Filosof Muslim, Bandung: Mizan. 